\title{
USE OF AGRO-INPUTS IN AGRICULTURAL PRODUCTION AND WATER RESOURCES POLLUTION: A CASE STUDY OF CHU-MANGO IN THE MEKONG RIVER DELTA, VIETNAM
}

\author{
TRUONG HONG VO TUAN KIET ${ }^{1}$, PHAM THI NGUYEN ${ }^{2} \&$ NGUYEN THI KIM THOA ${ }^{1}$ \\ ${ }^{1}$ Mekong Delta Development Research Institute, Can Tho University, Vietnam \\ ${ }^{2}$ School of Economics, Can Tho University, Vietnam
}

\begin{abstract}
This paper employed the Environmental Impact Quotient (EIQ) model to determine the impact of chemical fertilizer and pesticide on farm workers, consumers and the ecology, as well as imply potential threats of Chu-mango cultivation on water resource pollution. The findings indicate that the number of root fertilizer (N-P-K) is $624.1,542.5$ and $443.5 \mathrm{~kg} / \mathrm{ha}$ for seasons 1,2 and 3, respectively. The nitrogen and phosphates misuse could leach into groundwater or enter via surface runoff into waterways. The ecology components in Chu-mango farming is the most vulnerable objective among three seasons. The field use EIQ in season 1 is the highest $(1,058.56)$ in all of three seasons, then season 2 (747.06) and season 3 (592.34). Pesticides can move into water through direct application, runoff, and atmospheric deposition to contaminate water resources. One suggestion, therefore, is that the government could encourage mango growers to adopt good agricultural practices by training programs that raise their awareness of ecological protection. This policy would help to reject banned agrochemicals in mango production, which protects the water quality. Additionally, traceability code is needed, which would help farmers change the behavior of pesticide overuse, and is to carry out individual responsibilities for their products to communities. It not only reduces loadings of agricultural pollutants to water resources but also takes the potential trade benefit.
\end{abstract}

Keywords: Chu-mango, ground water, surface water, pollution.

\section{INTRODUCTION}

The global increasing demand for agricultural commodities, farmers are looking to increase productivity through the intensive use of inputs such as pesticides and chemical fertilizers as well as agricultural land expansion, irrigation system progression. This has transferred agricultural pollution to water bodies. Water pollution from unsustainable agricultural practices threatens human health and ecosystems. According to [1], agriculture accounts for $70 \%$ of total water consumption worldwide and is the single-largest contributor of non-pointsource pollution to surface water and groundwater. Agriculture intensification is often accompanied by increased soil erosion, salinity and sediment loads in water and by the excessive use of agricultural inputs (pesticides and fertilizers) to rise productivity.

Residues of chemical fertilizers and pesticides may wash off the field into rivers or leach through the soil into ground water. Irrigation can move salt and other dissolved minerals to surface water. That is reason why main pollution source of rivers and streams in the United States of America comes from agricultural farming [2]. Surface-water and groundwater pollution in China stem from nitrogen in agricultural production [3]. Insecticides, herbicides and fungicides are applied intensively in agriculture in many countries [4] especially in developing countries where is weak rule enforcement, and limited knowledge and awareness among farmers on the use of hazardous chemicals pose enormous challenges to the safe and sustainable management of pesticides. This can cause poison fish and wildlife, contaminate food sources, and destroy the habitat that animals use for protective cover. 
The study aims to identify the current status of chemical fertilizers and pesticides (insecticides, herbicides and fungicides) use in Chu-mango production as well as measure negative impacts of agro-inputs on health and ecology, especially is water resources. This helps more understanding regarding the causes and effects of agricultural water pollution in order to control and mitigate pollution loads from Chu-mango cultivation activities.

\section{MATERIALS AND METHODS}

\subsection{Sampling techniques}

Based on the secondary data of statistical yearbook in agricultural production, the study chose the three biggest production area of Chu-mango including: An Giang, Dong Thap and Vinh Long provinces in the Mekong River Delta (Fig. 1). Information on primary data was conducted several steps. Firstly, study group interviewed directly with agricultural extension workers in province and district level to identify big mango villages. Secondly, there were six discussion groups (4 people per group) in six Chu-mango production villages to determine essential elements before designing questionnaire. Thirdly, the research carried out trial survey 36 sampling observations (12 observations in each province). Finally, simple random technique was employed to select 522 sampling observations $(212,171$, and 139 observations for seasons 1,2, and 3, respectively) for computing the EIQ of the human health and ecological impacts.

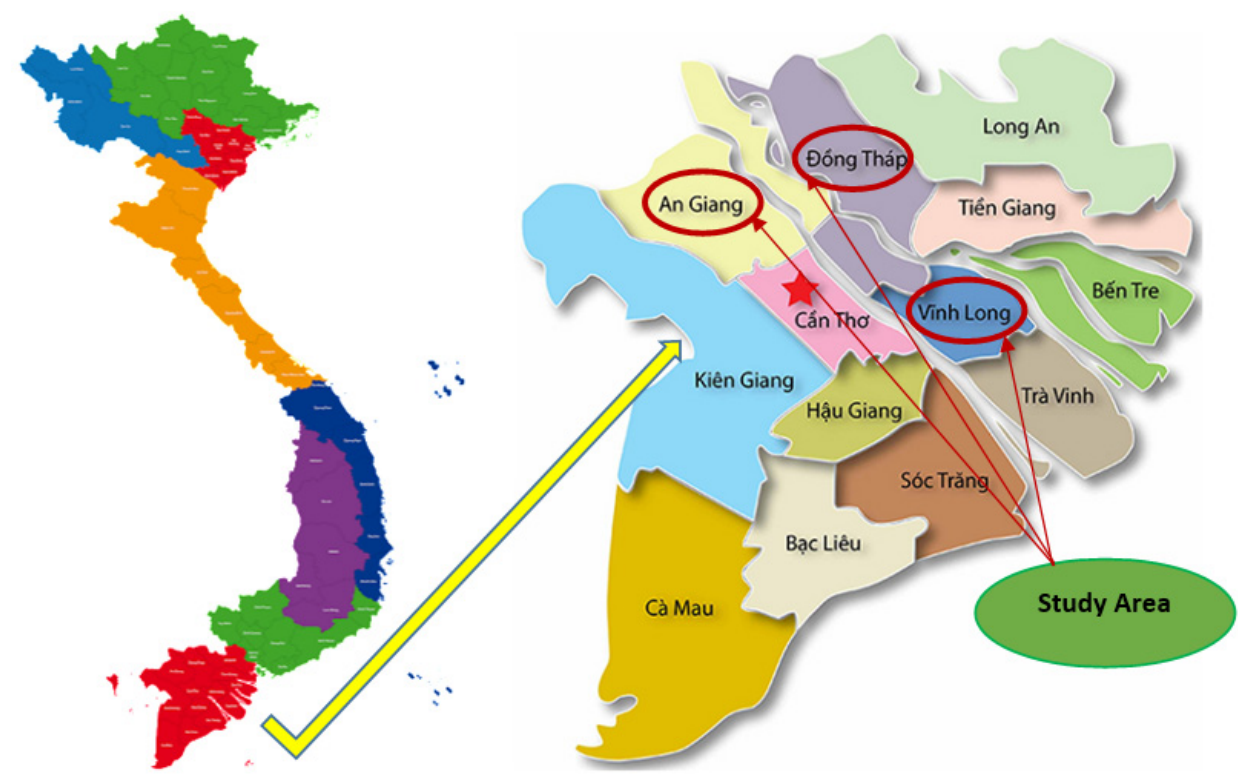

Figure 1: Study area in the Mekong Delta, Vietnam.

\subsection{Environment impact quotient model}

There are other measurements of ecological risk of agrochemical use [5]. However, assessments of pesticide applications still use Environment Impact Quotient (EIQ) for scientific and policy purposes [6]-[10]. The use of EIQ has been debated in the literature 
[11]-[13]. The EIQ model was developed by Kovach et al. [14] at Cornell University to quantify the effects of various crop pests and disease-control strategies on humans and the ecology.

Table 1: Definition for symbols and ratings for each toxicity category [14].

\begin{tabular}{|l|c|c|c|c|}
\hline Variables & Symbol & Score 1 & Score 3 & Score 5 \\
\hline $\begin{array}{l}\text { Long-term health effects } \\
\text { (chronic) }\end{array}$ & $\mathrm{c}$ & Little-none & Possible & Definite \\
\hline Dermal toxicity (Rat LD50) & $\mathrm{dt}$ & $>2,000 \mathrm{mg} / \mathrm{kg}$ & $200-2,000 \mathrm{mg} / \mathrm{kg}$ & $0-200 \mathrm{mg} / \mathrm{kg}$ \\
\hline Bird toxicity (8 day LC50) & $\mathrm{d}$ & $>1,000 \mathrm{ppm}$ & $100-1,000 \mathrm{ppm}$ & $1-100 \mathrm{ppm}$ \\
\hline Bee toxicity & $\mathrm{z}$ & Non-toxic & Moderately toxic & Highly toxic \\
\hline Beneficial arthropod toxicity & $\mathrm{b}$ & Low impact & Moderate & Severe impact \\
\hline Fish toxicity (96 h LC50) & $\mathrm{f}$ & $>10 \mathrm{ppm}$ & $1-10 \mathrm{ppm}$ & $<1 \mathrm{ppm}$ \\
\hline Plant surface half-life & $\mathrm{s}$ & $1-2$ weeks & $2-4$ weeks & $>4$ weeks \\
\hline Soil residue half-life (TI/2) & $\mathrm{p}$ & $<30$ days & $30-100$ days & $>100$ days \\
\hline Mode of action & $\mathrm{sy}$ & Non-system & Systemic & \\
\hline Leaching potential & 1 & Small & Medium & Large \\
\hline Surface runoff potential & $\mathrm{r}$ & Small & Medium & Large \\
\hline
\end{tabular}

The variables in Table 1 are used to computer eight ecological impact indicators (applicator, harvester, exposure, groundwater, fish, birds, bees, other beneficial insects). These scores are then further aggregated to represent the ecological impact on each of the three major profiles: farmer, consumer and ecology. Eventually, the synthesized EIQ score is the average of the three scores and it is calculated for each pesticide active ingredient. The EIQ formula can be divided into influences on the farm worker (applicator and harvester), consumer (exposure and groundwater effects), and ecology (fish, birds, bees, beneficial arthropod). The EIQ is specific to individual active ingredients that is calculated by eqn (1). The field use EIQ is specific to individual pesticide formulations, which may have multiple active ingredients. The field use EIQ for pesticide formulation is the sum of the EIQ's of the individual active ingredients weighted by both the proportion of the formulation each active ingredient comprises and the application rate of the formulation (eqn (2)). The higher values of the field use EIQ indicate greater relative risk. The EIQ formula is defined:

Total EIQ = farm worker + consumer + ecology:

$$
\{[\mathrm{c} *(\mathrm{dt} * 5)+(\mathrm{dt} * \mathrm{p})]+[(\mathrm{c} *(\mathrm{~s}+\mathrm{p}) / 2 * \mathrm{sy})+(1)]+[(\mathrm{f} * \mathrm{r})+(\mathrm{d} *(\mathrm{~s}+\mathrm{p}) / 2 * 3)+(\mathrm{z} * \mathrm{p} * 3)+(\mathrm{b} * \mathrm{p} * 5)]\} / 3
$$

where:

$\mathrm{c}=$ chronic toxicity,

$\mathrm{dt}=$ dermal toxicity,

$\mathrm{p}=$ plant surface residue half-life,

$\mathrm{s}=$ soil residue half-life,

sy $=$ systematicity,

$1=$ leaching potential,

$\mathrm{f}=$ fish toxicity,

$\mathrm{r}=$ surface loss,

$\mathrm{d}=$ bird toxicity,

$\mathrm{z}=$ bee toxicity, and $\mathrm{B}=$ beneficial arthropod activity. 
The Field Use EIQ = EIQ theorical values * \% active ingredient * rate/ha

Name list of active ingredients in the Table 2 is result of mango households' investigation in study area. Values of EI components (farm worker, consumer and ecology) and average EIQ are calculated based on eqn (1). In fact, these values are calculated by Cornell University (List of pesticide active ingredient EIQ values: A method to measure the environmental impact of pesticides, Table 2: list of pesticides (last updated May 2020)). They are considered as impact parameters (EIQ theoretical values) and is used in eqn (2) to calculate the field use EIQ.

Table 2: Theoretical values of the EIQ from Cornell University [15].

\begin{tabular}{|l|c|c|c|c|}
\hline \multirow{2}{*}{ Active ingredient } & \multicolumn{2}{|c|}{ EI component value } & Average \\
& Farm worker & Consumer & Ecology & EIQ val \\
\hline Paclobutrazol & 21.30 & 6.55 & 51.45 & 26.43 \\
\hline \multicolumn{4}{|c|}{ Herbicide } \\
\hline Glyphosate & 8.00 & 3.00 & 35.00 & 15.33 \\
\hline Paraquat & 31.95 & 6.33 & 35.92 & 24.73 \\
\hline 2,4-D & 24.00 & 7.00 & 31.00 & 20.67 \\
\hline \multicolumn{5}{|c|}{ Pesticide } \\
\hline Cypermethrin & 13.80 & 5.90 & 89.35 & 36.35 \\
\hline Chlorpyrifos & 6.00 & 2.00 & 72.55 & 26.85 \\
\hline Emamectin benzoate & 9.00 & 4.00 & 65.85 & 26.28 \\
\hline Abamectin & 13.80 & 3.90 & 86.35 & 34.68 \\
\hline Imidacloprid & 6.90 & 10.35 & 92.88 & 36.71 \\
\hline Permethrin & 12.00 & 5.00 & 71.00 & 29.33 \\
\hline \multicolumn{5}{|c|}{ Fungicide } \\
\hline Mancozeb & 20.25 & 8.13 & 48.79 & 25.72 \\
\hline Propiconazole & 12.00 & 19.00 & 63.90 & 31.63 \\
\hline Ziram & 24.00 & 9.00 & 42.45 & 25.15 \\
\hline Carbendazim & 25.00 & 40.50 & 86.00 & 50.50 \\
\hline Difenoconazole & 15.00 & 23.50 & 86.00 & 41.50 \\
\hline Tebuconazole & 20.00 & 31.00 & 70.00 & 40.33 \\
\hline Azoxystrobin & 8.10 & 6.05 & 66.62 & 26.92 \\
\hline Metalaxyl & 8.10 & 12.15 & 36.95 & 19.07 \\
\hline Trifloxystrobin & 12.15 & 10.23 & 66.95 & 29.78 \\
\hline
\end{tabular}

\section{RESULTS AND DISCUSSION}

3.1 The situation of chemical fertilizer use in Chu-mango production

Season 1 (Off-season): flowering from May to June, harvesting from mid-August to October. Season 2 (Late season): flowering from late August to October, harvesting from late 
November to February of the next year (this is known as the festival season because the harvesting time is focused on important festivals such as those that take place in mid-October and mid-January according to the lunar calendar (Buddhist days), Christmas, New Year, and Lunar New Year. Season 3 is natural season (flowering from January to February, harvesting from mid-April to late June) or early season (flowering from November to December, harvesting from mid-February to April). The natural and early season of sunny season are collectively known as season 3, which takes place in favorable climate conditions. Hence, the agro-inputs during this season differs from those of season 1 and season 2.

Chu-mango growers provide nutrients to their mango orchards by applying the phosphorus, nitrogen, and potassium in the form of chemical fertilizers to increase productivity. The role of these elements in mango production has been mentioned in previous studies such as vegetative growth, flowering stimulation, fruit quality, and yield increase. Besides, they are not only influence directly on plants tissues but also effect on synthesis of other nutrients [16]. The nitrogen fertilizer is positive relationship with mango productivity in Florida [17]. Moreover, a proper combination of the phosphorus, nitrogen, and potassium contributes to improve mango productivity significantly. The phosphorus can stimulate progression of root, branch, fruit, and absorption of water and nutrients [18].

Information about chemical fertilizer use in Chu-mango farming is presented in the Table 3. Overall, there is difference in chemical fertilizer use among seasons. The study result shows that the number of root fertilizer $(\mathrm{N}-\mathrm{P}-\mathrm{K})$ in season 1 is the highest $(624.1 \mathrm{~kg} / \mathrm{ha})$, follows by season $2(542.5 \mathrm{~kg} / \mathrm{ha})$ and in season $3(443.5 \mathrm{~kg} / \mathrm{ha})$. By comparison with the result of [19], the number of chemical fertilizer use in countries is demonstrated 100.4 in Turkey, 665.5 in the Netherlands, 624.8 in Egypt, 373.2 in Japan, 301.5 in China, 287.5 in Britain, 205.4 in Germany; 180.1 in France, 160.8 in the USA, 126.4 in Italy, 121.4 in India, 115.4 in Greece and 106.9 in Indonesia kg/ha respectively. From the result shows that Chumango production in the Mekong River Delta uses chemical fertilizer highly. It is noticeable that the nitrogen fertilizer overuse can cause reduction of yellow skin in mature mango fruits, the anthracnose rise [20]. Furthermore, the nitrogen and phosphates overuse can leach into groundwater or move via surface runoff into waterways. Phosphate is not as soluble as nitrate and ammonia and tends to get adsorbed onto soil particles and enter water bodies thorough soil erosion.

Table 3: The number of chemical fertilizer in Chu-mango cultivation. (Source: Field Survey Data, 2018.)

\begin{tabular}{|l|c|c|c|}
\hline Items & $\begin{array}{c}\text { Season 1 } \\
(\mathrm{n}=212)\end{array}$ & $\begin{array}{c}\text { Season 2 } \\
(\mathrm{n}=171)\end{array}$ & $\begin{array}{c}\text { Season 3 } \\
(\mathrm{n}=139)\end{array}$ \\
\hline Root fertilizer & & & \\
\hline N: nitrogen (kg/ha) & $268.8 \pm 523.2$ & $232.0 \pm 298.6$ & $181.0 \pm 211.7$ \\
\hline P: phosphorus (kg/ha) & $207.6 \pm 575.2$ & $150.3 \pm 209.0$ & $144.3 \pm 180.1$ \\
\hline K: potassium (kg/ha) & $147.7 \pm 276.8$ & $160.2 \pm 291.4$ & $118.2 \pm 156.1$ \\
\hline Microelements (gr/ha) & $0.103 \pm 0.973$ & $0.011 \pm 0.146$ & $0.088 \pm 1.049$ \\
\hline Leaf fertilizer (Liquid) for flowering stimulation \\
\hline N: nitrogen (kg/ha) & $10.4 \pm 12.4$ & $11.5 \pm 24.0$ & $7.7 \pm 8.6$ \\
\hline P: phosphorus (kg/ha) & $1.6 \pm 8.6$ & $1.1 \pm 6.6$ & $1.2 \pm 7.0$ \\
\hline K: potassium (kg/ha) & $21.0 \pm 28.3$ & $21.3 \pm 33.5$ & $15.9 \pm 22$ \\
\hline Microelements (gr/ha) & $21.8 .5 \pm 86.1$ & $33.6 \pm 150.8$ & $60.5 \pm 542.0$ \\
\hline
\end{tabular}


In Chu-mango cultivation, growers usually use the liquid fertilizer ( $\mathrm{N}-\mathrm{P}-\mathrm{K})$ to spray on mango leaves for flowering stimulation. The liquid fertilizer consists of a large amount of microelements ( $\mathrm{Mn}, \mathrm{Zn}, \mathrm{Cu}, \mathrm{Mo}, \mathrm{S}$ and $\mathrm{B}$ ) compared to the root fertilizer. In general, two key factors in the liquid fertilizer are the nitrogen and potassium. The role of potassium nitrate is flowering stimulation for mango orchards in off-season as well as increase flower induction, fruit set and fruit retention [21].

In summary, chemical fertilizer use in mango production need a carefully management and control. If it is misused, it will take place negative impacts on human health (farm worker, consumer) and ecology (soil, water, air, terrestrial and aquatic ecosystems). The nitrogenous fertilizer is considered one of the most important inputs in agricultural production. Its overuse causes air pollution by nitrogen oxides $\left(\mathrm{NO}, \mathrm{N}_{2} \mathrm{O}, \mathrm{NO}_{2}\right)$ emissions. The nitrogenous fertilizer overuse in mango cultivation only absorb a part to soil, and the rest of the nitrogenous fertilizer is lost evaporation, and react organic compounds in the clay soil and the remaining interfere surface and ground water. It can cause algae blooms, and kill fish by removing oxygen from the water.

\subsection{Human health and ecology impacts in Chu-mango production}

The study of [22] showed that EIQ classification values for all the pesticide used in mango production is $30 \%, 25 \%$ and $45 \%$ of those pesticides have been rated as low (EIQ $=0$ to 20 ), moderate (EIQ $=21$ to 40 ) and high (EIQ $\geq 41$ ) respectively. Among three seasons, the findings of the study shows that none of active ingredients belong to moderate risk group among three seasons. There are four active ingredients EIQ more than 41 (high risk group) including: the paclobutrazol, mancozeb, propineb and ziram. The rest of active ingredients is low risk group.

In season 1 (Table 4), the greatest percentage of pesticide is used by the fungicide, at $50.82 \%$. Less than a small number, namely $40.86 \%$, is applied from the paclobutrazol (a growth control for flowering stimulation). The insecticide accounts for $4.88 \%$ of pesticide usage, leaving the herbicide at only 0.43 . Noticeably, the paclobutrazol, and mancozeb, propineb and ziram of the fungicide make up $91.3 \%$ of total pesticide use in Chu-mango farming.

The most outstanding feature of the Table 5 is that the vast majority of the fungicide use in Chu-mango cultivation $(64.74 \%)$ contrasting with a minority of the herbicide $(0.65 \%)$ using in season 2. Just over a quarter, namely $27.89 \%$, go to the paclobutrazol, follows by the insecticide at $6.72 \%$. Particularly, four active ingredients play vital role in Chu-mango farming including: the paclobutrazol, and mancozeb, propineb and ziram. These active ingredients are responsible for $87.53 \%$ in total of pesticide usage.

In season 3 (Table 6), the fungicide still occupies the highest proportion of the total pesticide, at $76.22 \%$, whereas the opposite is true of herbicide $(0.45 \%)$. The paclobutrazol ranks second in terms of popularity, at $16.93 \%$, follows by the insecticide at $6.39 \%$. The season 3 resembles the season 2; the paclobutrazol, and mancozeb, propineb and ziram are popular active ingredients in Chu-mango production with approximately $86.76 \%$ of the total pesticide use. Thus, reduction of pesticide use in Chu-mango production can conducted by decreasing these active ingredients. 
Table 4: The practical values of the health and ecology impacts (EIQ) in season 1. (Source: Field Survey Data, 2018.)

\begin{tabular}{|l|c|c|c|c|c|c|}
\hline \multirow{2}{*}{$\begin{array}{l}\text { Active } \\
\text { ingredients }\end{array}$} & \multirow{2}{*}{ Quantity } & \multicolumn{3}{|c|}{ EIQ component } & \multirow{2}{*}{$\begin{array}{c}\text { EIQ } \\
\text { average }\end{array}$} & \multirow{2}{*}{ Percent } \\
\cline { 3 - 5 } Paclobutrazol & $\mathbf{1 7 . 5 7}$ & $\mathbf{3 7 4 . 2 0}$ & $\mathbf{1 1 5 . 0 7}$ & $\mathbf{9 0 3 . 8 7}$ & $\mathbf{4 6 4 . 3 2}$ & $\mathbf{4 3 . 8 6}$ \\
\hline Herbicide & $\mathbf{0 . 2 4}$ & $\mathbf{4 . 3 7}$ & $\mathbf{1 . 1 3}$ & $\mathbf{8 . 3 0}$ & $\mathbf{4 . 6 0}$ & $\mathbf{0 . 4 3}$ \\
\hline Glyphosate & 0.12 & 0.99 & 0.37 & 4.33 & 1.90 & 0.18 \\
\hline Paraquat & 0.08 & 2.40 & 0.48 & 2.70 & 1.86 & 0.18 \\
\hline 2,4-D dimethyl & 0.04 & 0.98 & 0.29 & 1.27 & 0.84 & 0.08 \\
\hline Insecticide & $\mathbf{1 . 6 5}$ & $\mathbf{1 5 . 5 3}$ & $\mathbf{7 . 7 0}$ & $\mathbf{1 3 1 . 7 5}$ & $\mathbf{5 1 . 6 6}$ & $\mathbf{4 . 8 8}$ \\
\hline Cypermethrin & 0.53 & 7.30 & 3.12 & 47.29 & 19.24 & 1.82 \\
\hline Chlorpyrifos & 0.59 & 3.51 & 1.17 & 42.49 & 15.72 & 1.49 \\
\hline Emamectin & 0.28 & 2.50 & 1.11 & 18.27 & 7.29 & 0.69 \\
\hline Abamectin & 0.06 & 0.80 & 0.23 & 5.02 & 2.02 & 0.19 \\
\hline Imidacloprid & 0.20 & 1.37 & 2.05 & 18.44 & 7.29 & 0.69 \\
\hline Permethrin & 0.00 & 0.04 & 0.02 & 0.25 & 0.10 & 0.01 \\
\hline Fungicide & $\mathbf{1 9 . 3 2}$ & $\mathbf{3 5 7 . 8 5}$ & $\mathbf{2 3 3 . 0 9}$ & $\mathbf{1 , 0 2 3 . 1 6}$ & $\mathbf{5 3 7 . 9 8}$ & $\mathbf{5 0 . 8 2}$ \\
\hline Mancozeb & 8.89 & 179.99 & 72.26 & 433.66 & 228.61 & 21.60 \\
\hline Propineb & 5.38 & 64.51 & 102.14 & 343.52 & 170.04 & 16.06 \\
\hline Ziram & 4.12 & 98.79 & 37.05 & 174.73 & 103.52 & 9.78 \\
\hline Carbendazim & 0.08 & 2.10 & 3.40 & 7.22 & 4.24 & 0.40 \\
\hline Difenoconazole & 0.40 & 5.93 & 9.28 & 33.97 & 16.39 & 1.55 \\
\hline Tebuconazole & 0.23 & 4.66 & 7.22 & 16.31 & 9.40 & 0.89 \\
\hline Azoxystrobin & 0.17 & 1.41 & 1.05 & 11.59 & 4.68 & 0.44 \\
\hline Metalaxyl & 0.05 & 0.43 & 0.64 & 1.96 & 1.01 & 0.10 \\
\hline Trifloxystrobin & 0.00 & 0.03 & 0.03 & 0.18 & 0.08 & 0.01 \\
\hline Field use EIQ & $\mathbf{3 8 . 7 8}$ & $\mathbf{7 5 1 . 9 5}$ & $\mathbf{3 5 6 . 9 9}$ & $\mathbf{2 , 0 6 7 . 0 8}$ & $\mathbf{1 , 0 5 8 . 5 6}$ & $\mathbf{1 0 0 . 0 0}$ \\
\hline & & & & & & \\
\hline
\end{tabular}

Unit: $\mathrm{kg} / \mathrm{ha}$. 
Table 5: The practical values of the health and ecology impacts (EIQ) in season 2. (Source: Field Survey Data, 2018.)

\begin{tabular}{|c|c|c|c|c|c|c|}
\hline \multirow{2}{*}{$\begin{array}{l}\text { Active } \\
\text { ingredients }\end{array}$} & \multirow{2}{*}{ Quantity } & \multicolumn{3}{|c|}{ EIQ component } & \multirow{2}{*}{$\begin{array}{c}\text { EIQ } \\
\text { average }\end{array}$} & \multirow{2}{*}{ Percent } \\
\hline & & Farmer & Consumer & Ecology & & \\
\hline Paclobutrazol & 7.88 & 167.92 & 51.64 & 405.61 & 208.36 & 27.89 \\
\hline Herbicide & 0.26 & 4.23 & 1.17 & 9.13 & 4.85 & 0.65 \\
\hline Glyphosate & 0.16 & 1.28 & 0.48 & 5.62 & 2.46 & 0.33 \\
\hline Paraquat & 0.06 & 1.79 & 0.35 & 2.01 & 1.38 & 0.18 \\
\hline 2,4-D dimethyl & 0.05 & 1.16 & 0.34 & 1.50 & 1.00 & 0.13 \\
\hline Insecticide & 1.60 & 15.27 & 7.21 & 128.09 & 50.19 & 6.72 \\
\hline Cypermethrin & 0.57 & 7.92 & 3.39 & 51.30 & 20.87 & 2.79 \\
\hline Chlorpyrifos & 0.61 & 3.67 & 1.22 & 44.34 & 16.41 & 2.20 \\
\hline Emamectin & 0.19 & 1.74 & 0.77 & 12.72 & 5.08 & 0.68 \\
\hline Abamectin & 0.06 & 0.89 & 0.25 & 5.55 & 2.23 & 0.30 \\
\hline Imidacloprid & 0.15 & 1.05 & 1.58 & 14.19 & 5.61 & 0.75 \\
\hline Permethrin & - & - & - & - & - & - \\
\hline Fungicide & 17.08 & 308.42 & 218.76 & 923.94 & 483.66 & 64.74 \\
\hline Mancozeb & 7.01 & 142.01 & 57.01 & 342.15 & 180.37 & 24.14 \\
\hline Propineb & 5.63 & 67.59 & 107.02 & 359.93 & 178.16 & 23.85 \\
\hline Ziram & 3.46 & 83.04 & 31.14 & 146.87 & 87.02 & 11.65 \\
\hline Carbendazim & 0.16 & 3.98 & 6.45 & 13.71 & 8.05 & 1.08 \\
\hline Difenoconazole & 0.37 & 5.59 & 8.76 & 32.07 & 15.47 & 2.07 \\
\hline Tebuconazole & 0.22 & 4.45 & 6.90 & 15.58 & 8.98 & 1.20 \\
\hline Azoxystrobin & 0.19 & 1.53 & 1.15 & 12.62 & 5.10 & 0.68 \\
\hline Metalaxyl & 0.03 & 0.21 & 0.31 & 0.94 & 0.48 & 0.06 \\
\hline Trifloxystrobin & 0.00 & 0.01 & 0.01 & 0.08 & 0.04 & 0.01 \\
\hline Field use EIQ & 26.82 & 495.84 & 278.78 & $1,466.77$ & 747.06 & 100.00 \\
\hline
\end{tabular}

Unit: $\mathrm{kg} / \mathrm{ha}$. 
Table 6: The practical values of the health and ecology impacts (EIQ) in season 3. (Source: Field Survey Data, 2018.)

\begin{tabular}{|c|c|c|c|c|c|c|}
\hline \multirow{2}{*}{$\begin{array}{l}\text { Active } \\
\text { ingredients }\end{array}$} & \multirow{2}{*}{ Quantity } & \multicolumn{3}{|c|}{ EIQ component } & \multirow{2}{*}{$\begin{array}{c}\text { EIQ } \\
\text { Average }\end{array}$} & \multirow{2}{*}{ Percent } \\
\hline & & Farmer & Consumer & Ecology & & \\
\hline Paclobutrazol & 3.79 & 80.83 & 24.86 & 195.24 & 100.29 & 16.93 \\
\hline Herbicide & 0.15 & 2.23 & 0.63 & 5.12 & 2.66 & 0.45 \\
\hline Glyphosate & 0.10 & 0.78 & 0.29 & 3.41 & 1.49 & 0.25 \\
\hline Paraquat & 0.03 & 0.93 & 0.18 & 1.05 & 0.72 & 0.12 \\
\hline 2,4-D dimethyl & 0.02 & 0.51 & 0.15 & 0.66 & 0.44 & 0.07 \\
\hline Insecticide & 1.21 & 11.17 & 5.94 & 96.52 & 37.88 & 6.39 \\
\hline Cypermethrin & 0.34 & 4.64 & 1.99 & 30.07 & 12.23 & 2.06 \\
\hline Chlorpyrifos & 0.39 & 2.33 & 0.78 & 28.22 & 10.44 & 1.76 \\
\hline Emamectin & 0.25 & 2.23 & 0.99 & 16.28 & 6.50 & 1.10 \\
\hline Abamectin & 0.04 & 0.61 & 0.17 & 3.85 & 1.54 & 0.26 \\
\hline Imidacloprid & 0.19 & 1.34 & 2.01 & 18.00 & 7.12 & 1.20 \\
\hline Permethrin & 0.00 & 0.02 & 0.01 & 0.10 & 0.04 & 0.01 \\
\hline Fungicide & 16.13 & 296.20 & 197.10 & 861.37 & 451.51 & 76.22 \\
\hline Mancozeb & 7.84 & 158.71 & 63.72 & 382.39 & 201.58 & 34.03 \\
\hline Propineb & 4.53 & 54.41 & 86.14 & 289.71 & 143.40 & 24.21 \\
\hline Ziram & 2.86 & 68.54 & 25.70 & 121.24 & 71.83 & 12.13 \\
\hline Carbendazim & 0.10 & 2.58 & 4.18 & 8.88 & 5.21 & 0.88 \\
\hline Difenoconazole & 0.29 & 4.38 & 6.86 & 25.09 & 12.11 & 2.04 \\
\hline Tebuconazole & 0.29 & 5.79 & 8.98 & 20.28 & 11.68 & 1.97 \\
\hline Azoxystrobin & 0.19 & 1.51 & 1.13 & 12.45 & 5.03 & 0.85 \\
\hline Metalaxyl & 0.03 & 0.22 & 0.34 & 1.02 & 0.53 & 0.09 \\
\hline Trifloxystrobin & 0.00 & 0.06 & 0.05 & 0.32 & 0.14 & 0.02 \\
\hline Field use EIQ & 21.29 & 390.43 & 228.52 & $1,158.25$ & $\mathbf{5 9 2 . 3 4}$ & 100.00 \\
\hline
\end{tabular}

Unit: $\mathrm{kg} / \mathrm{ha}$. 
It is apparent that the ecology is the most vulnerable objective by pesticide use because its EIQ components is the highest in three EIQ components (farm worker, consumer) among three seasons. In detail, EIQ component of ecology in season 1 is 2,067.08. It is 2.7 times that of farm worker and 5.8 times that of consumer. In season 2, the ecology EIQ is 1,466.77, about 3 times farm worker EIQ and 5.3 times consumer EIQ. The number in season 3 is 1,158.25, approximately 3 times farm worker EIQ and 5.1 times consumer EIQ. Especially, Chu- mango cultivation in season 1 is the most negative impact on ecology in all of year. It is more than 1.4 and 1.8 times for seasons 2 and 3. Similarly, the field use EIQ in season 1 is the highest $(1,058.56)$ in all of three seasons, then seasons 2 (747.06) and season 3 (592.34). Chu-mango production in season 3 is natural crop with favorable climate condition. Thus, the amount of pesticide use much less than compared to season 1 and 2. There is a dearth of empirical studies on EIQ on fruit in Vietnam, especially is mango fruit. This is difficult to compare the research result to previous studies in Vietnam. Therefore, this study provides empirical data on EIQ on mango fruit production as a reference source for next studies. The finding indicates that the field use EIQ of Chu-mango production in three seasons is lower than that of mango production in Kenya. This figure in Kenya is $10,006.73 \mathrm{~kg} / \mathrm{ha}(44,049.67$ $\mathrm{kg} / \mathrm{acre}$ ) [23], and greater than 9.5, 13.4, and 16.9 times in seasons 1,2 , and 3 respectively in Chu-mango production in the Mekong River Delta, Vietnam.

Main cause of chemical fertilizer and pesticide overuse of seasons 1 and 2 is to control insect pests, fungus, and disease as well supply nutrients mango orchards in unfavorable climate condition of off-season in order to ensure mango productivity. Agrochemicals can move to water through direct application, runoff, and atmospheric deposition. If it does not control well, it will contaminate water resources. This become more and more dangerous pose risks to human health by probable human carcinogens of pesticide, especially is in developing countries that farmers directly use highly hazardous pesticide. Besides, pesticide residues harmful impact on freshwater and marine organisms as impact of eutrophication on aquatic ecosystem [24].

In the circumstance, the government could encourage mango growers to adopt good agricultural practices by training programs that raise their awareness on ecological protection. This policy would help to reject banned agrochemicals in mango production, which protect water quality. Additionally, traceability is needed, which would help of farmer change behavior of pesticide overuse, is to carry out individual responsibilities for their products to communities. It not only reduces loadings of agricultural pollutants to water resources but also take the potential trade benefit. The study is conducted in the Mekong River Delta where is famous for the cultivation of mango as well as is considered central mango production in Vietnam, as it accounts for $62.8 \%$ of the mango production volume and for $46.3 \%$ of the mango production area in Vietnam [25]. Thus, the result is typical as a study case in Vietnam.

\section{CONCLUSIONS}

The N-P-K application in Chu-mango production in the Mekong River Delta is relatively high compared to other countries. The number of root fertilizer (N-P-K) in season 1 is the highest $(624.1 \mathrm{~kg} / \mathrm{ha})$, follows by season $2(542.5 \mathrm{~kg} / \mathrm{ha})$ and in season $3(443.5 \mathrm{~kg} / \mathrm{ha})$. Chemical fertilizer use in mango production need a carefully management and control. If it is misused, it will take place negative impacts on human health (farm worker, consumer) and ecology (soil, water, air, terrestrial and aquatic ecosystems). Importantly, the nitrogen and phosphates overuse can leach into groundwater or move via surface runoff into waterways. 
Phosphate is not as soluble as nitrate and ammonia and tends to get adsorbed onto soil particles and enter water bodies thorough soil erosion.

Chu-mango cultivation in season 1 is the most negative impact on ecology in all of year. It is more than 1.4 and 1.8 times for seasons 2 and 3. Similarly, the field use EIQ in season 1 is the highest $(1,058.56)$ in all of three seasons, then seasons 2 (747.06) and season 3 (592.34). Chu-mango production in season 3 is natural crop with favorable climate condition. Thus, the amount of pesticide use much less than compared to season 1 and 2 (off-season). Agrochemicals can move to water through direct application, runoff, and atmospheric deposition. If it does not control well, it will contaminate water resources.

\section{ACKNOWLEDGEMENTS}

The study used data source from project "Value chain development of Vietnamese mango fulfilling requirement for domestic and international markets" (2017-2020), code: KHCNTNB.ĐT/14-19/C14). The authors would like to thank the financial support from program "Technology and science program for sustainable development in Mekong Delta region" from Ministry of Technology and Science in Vietnam.

\section{REFERENCES}

[1] F.A.O., Water Pollution from Agriculture: A Global Review, Rome, 35 pp., 2017.

[2] U.S. E.P.A., Water Quality Assessment and TMDL Information, United States Environmental Protection Agency (US EPA): Washington, DC, 2016. https://ofmpub.epa.gov/waters10/attains_index.home.

[3] F.A.O., Guidelines to control water pollution from agriculture in China. Water Report 40, Rome, 197 pp., 2013.

[4] Schreinemachers, P. \& Tipraqsa, P., Agricultural pesticides and land use intensification in high, middle and low income countries. Food Policy, 37, pp. 616626, 2012.

[5] Peterson, R.K.D., Comparing ecological risks of pesticides: The utility of a risk quotient ranking approach across refinements of exposure. Pest Management Science, 62, pp. 46-56, 2006.

[6] Bahlai, C.A., Xue, Y., McCreary, C.M., Schaafsma, A.W. \& Hallett, R.H., Choosing organic pesticides over synthetic pesticides may not effectively mitigate environmental risk in soybeans. PLoS One, 5, p. e11250, 2010.

[7] Cross, P. \& Edwards-Jones, G., Variation in pesticide hazard from arable crop production in Great Britain from 1992 to 2002: Pesticide risk indices and policy analysis. Crop Protection, 25, pp. 1101-1108, 2006.

[8] Peck, G.M., Merwin, I.A., Brown, M.G. \& Agnello, A.M., Integrated and organic fruit production systems for 'Liberty' Apple in the Northeast United States: A systemsbased evaluation. Hortscience, 45, pp. 1038-1048, 2010.

[9] Soltani, N., Stewart, C.L., Nurse, R.E., Van Eerd, L.L., Vyn, R.J. \& Sikkema, P.H., Weed control, environmental impact and profitability of weed management strategies in glyphosate-tolerant corn. American Journal of Plant Sciences, 3, pp. 1594-1607, 2012.

[10] Stewart, C.L., Nurse, R.E., Van Eerd, L.L., Vyn, R.J. \& Sikkema, P.H., Weed control, environmental impact and profitability of weed management strategies in glyphosateresistant soybean. Weed Technology, 25, pp. 535-541, 2011.

[11] Kniss, A.R. \& Coburn, C.W., Quantitative evaluation of the environmental impact quotient (EIQ) for comparing herbicides. PLoS One, 10(6), 2015. 
[12] Peterson, R.K.D. \& Schleier, J.J., A probabilistic analysis reveals fundamental limitations with the environmental impact quotient and similar systems for rating pesticide risks. PeerJ, 2, 2014.

[13] Gallivan, G.J., Beaton, D., McGee, B. \& Berges, H., Survey of pesticide use and evaluation of the changes in pesticide risk on agricultural crops in Ontario in 2008. New Directions Report, 48 p., 2010.

[14] Kovach, J., Petzoldt, C., Degni, J. \& Tette, J., A method to measure the environmental impact of pesticides. New York's Food and Life Sciences Bulletin, 139, pp. 1-8, 1992.

[15] Cornell, C.A.L.S., New York State integrated pest management: List of pesticide active ingredient EIQ values: A method to measure the environmental impact of pesticides, Table 2: list of pesticides (last updated May 2020). College of Agriculture and Life Sciences, Cornell University, 2020. https://nysipm.cornell.edu/eiq/listpesticide-active-ingredient-eiq-values/.

[16] Sen, P.K., Roy, P.K. \& De, B.N., Hunger signs on mango. Indian Journal of Horticulture, 5, pp. 35-44, 1947.

[17] Young, T.W., Koo, R.C.J. \& Miner, J.T., Effects of nitrogen, potassium and calcium fertilization on Kent mangos on deep, acid, sandy soil. Florida State Horticultural Society, pp. 364-371, 1962.

[18] Samra, J.S. \& Arora, Y.K., Mineral nutrition. The Mango, Botany, Production and Uses, ed. R.E. Litz, CAB International: Wallingford, UK, pp. 175-201, 1997.

[19] FAO, Resource STAT-Fertilizer, Food and Agriculture Organization of the United Nations, 2009. http://faostat.fao.org/site/575/DesktopDefault.aspx?PageID=575\# ancor. Accessed on: 12 Mar. 2009.

[20] Bally, I.S.E., Hofman, P.J., Irving, D.E., Coates, L.M. \& Dann, E.K., The effects of nitrogen on postharvest disease in mango (Mangifera Indica L. 'Keitt'). Acta Horticulturae, 820, pp. 365-370, 2009.

[21] Shinde, A.K., Dabke, D.J., Jadhav, B.B., Landalkar, M.P. \& Burondkar, M.M., Effect of dose and source of potassium on yield and quality of Alphonso mango (Mangifera indica L.). Indian Journal of Agricultural Science, 76, pp. 213-217, 2006.

[22] Mazlan, N. \& Mumford, J., Insecticide use in cabbage pest management in the Cameron Highlands, Malaysia. Crop Protection, 24(1), pp. 31-39, 2005.

[23] Mwungu, C.M., Muriithi, B., Affognon, H., Githiomi, C., Diiro, G. \& Ekesi, S., Health and environmental effects of adopting an integrated fruit fly management strategy among mango farmers in Kenya. African Journal of Agricultural and Resource Economics, 15(1), pp. 14-26, 2020.

[24] Pait, A., DeSouza, A. \& Farrow, D., Agricultural pesticide use in coastal areas: A national summary. U.S. Department of Commerce, National Oceanic and Atmospheric Administration, Sep. 1992.

[25] G.S.O. (General Statistic Office of Vietnam), Statistical Year Book 2019, Statistical Publishing House: Hanoi City, Vietnam, 2020. 